\title{
Conclusion: Farewell
}

A book of quotations can never be complete.

-Anonymous ${ }^{1}$

A poem is never finished, it is only abandoned.

—W. H. Auden, $1967^{2}$

Fare thee well! and if forever,

Still forever, fare thee well.

—Lord Byron, 1816

${ }^{1}$ I have seen this quote attributed to some Robert M. Hamilton, but could not find a reliable confirmation of this authorship.

${ }^{2}$ This is a succinct paraphrase of an earlier and much longer sentence by Paul Valéry. (Auden cited him as the author.) It was later repeated, about books, by Gene Fowler.

(C) The Author(s), under exclusive license to Springer Nature Switzerland AG 2021

K. K. Likharev (ed.), Essential Quotes for Scientists and Engineers, 